\title{
The Application of Informal Assessment of Core Competencies within Vocational High Schools
}

\author{
Soeprijanto $^{1, *}$, Achmad Ridwan ${ }^{2}$ \\ ${ }^{1}$ Program in Technology and Vocational Education, Faculty of Engineering, Universitas Negeri Jakarta, Indonesia \\ ${ }^{2}$ Doctoral Program Research and Education Evaluation, Universitas Negeri Jakarta, Indonesia
}

Received June 26, 2020; Revised August 7, 2020; Accepted August 28, 2020

\begin{abstract}
Cite This Paper in the following Citation Styles
(a): [1] Soeprijanto, Achmad Ridwan, "The Application of Informal Assessment of Core Competencies within Vocational High Schools," Universal Journal of Educational Research, Vol. 8, No. 10, pp. 4959 - 4966, 2020. DOI: 10.13189/ujer.2020.081068.
\end{abstract}

(b): Soeprijanto, Achmad Ridwan (2020). The Application of Informal Assessment of Core Competencies within Vocational High Schools. Universal Journal of Educational Research, 8(10), 4959 - 4966. DOI: 10.13189/ujer.2020.081068.

Copyright $\subseteq 2020$ by authors, all rights reserved. Authors agree that this article remains permanently open access under the terms of the Creative Commons Attribution License 4.0 International License

\begin{abstract}
This study aims to determine the extent to which teachers in Indonesian vocational high schools apply informal assessments to evaluate learning outcomes. The problems in this study are the development of using informal assessment across four competencies in vocational high schools, the main reasons for conducting this evaluation, and the data collection techniques in assessing students' skills informally. This study applies a survey method with a descriptive analysis to evaluate the application of informal assessment across the four keys: religious, social, knowledge, and skills competencies. The survey was conducted within 98 Schools, across 21 Indonesian Provinces, and included 183 teachers. The results show that, first, all the responding teachers apply informal assessment methods across all four competencies because of the school recommendations. Second, teachers used formal assessments to fulfill the data for students who are in trouble. The study also found that teachers have the highest tendency to apply informal assessment based on four competencies, which was religious for $76 \%$. Finally, the study identifies that teachers favor observation checklists (80\%) to gather informal assessment data. This study's contribution is to prove the implementation of informal assessment based on four competencies and the importance of this evaluation system towards vocational high school students' outcomes.
\end{abstract}

Keywords Informal Assessment, Core Competencies, Vocational School, Students' Learning Outcomes

\section{Introduction}

Assessment is an integral part of learning evaluation. There are three key activities in learning evaluation: measurement, assessment, and evaluation. According to [1], analysis is a set of rules for assigning numbers to represent objects, straits, attributes, and drill behaviors. Assessment can be defined as all activities that teachers and students undertake to obtain information that can be used to change teaching and learning. This includes teacher observation and analysis of students' work, including homework, tests, essays, reports, practical procedures, and classroom discussions. Assessment can be used to clarify teachers' expectations of their students [2]. It can support the quality of teaching and learning and is an essential part of education [3]. Teachers establish criteria to grade students [4] and to define the assessment [2].

Teachers assess students' work through formative tests, summative tests, and developmental tests. Formative assessment can inform students of their learning gaps; therefore, it can improve their understanding and guide their learning [5]. Formative assessments can be both formal and informal. Formal formative assessments focus on students' conceptualization and understanding [6], while informal formative assessments include the interactions, responses, and feedback between students and 
teachers [7]. Informal assessment is an effective way for teachers to listen to students and assist them in understanding the topic [8]. Teachers can measure understanding by their students' output, such as national examinations and tests, and their input, such as their scores in standard cognitive abilities tests or data obtained throughout the school year [9].

Assessment applied in the context of evaluating learning outcomes in schools can be formal and informal. Formal assessment, whereby data are measured formally, occurs through daily tests (formative), midterm tests (sub-summative) and final end-of-semester (summative) exams. According to [10], formal assessment information is collected through standardized tests, whereas informal assessment information is based on careful observations of behavior. According to [11], informal assessment constitutes one of the fundamental mechanisms by which learning occurs. It also provides opportunities to a student to evaluate their performance so as to assist in achieving their learning goals [12]. Informal assessments can provide proof of students' understanding [13], [14], [11], [15], [16]. Informal formative assessments allow teachers to evaluate their students' understanding by observing how they respond, their problem-solving skills, and their reactions when they make a mistake. Teachers can then determine a course of action based on this proof of their students' learning conception and choose the most appropriate practices to guide and support their students' learning [16]. Teachers conducting informal assessments should have strategies in place to provide a clear link between the curriculum objective and the activity, to ensure comprehensive evidence can be obtained, and to enable regular or continuous evaluation [17], [15].

[18] describe informal formative assessment as an ongoing strategy that helps teachers obtain information from students that can be immediately used in instruction. Informal assessment can be in the form of comments from teachers including those spoken during the learning process. Informal assessment can also be applied when students conduct experiments, by applying the concept of learning through a test so that they successfully understand and apply the knowledge gained. According to [9], methods for informal assessment can be divided into two main types: unstructured methods, such as student work samples, and journals; and structured methods, such as checklists, observations, assignments, and homework.

The formal assessment character uses exam questions that are developed based on the applicable standard reference. Legal steps or standard mechanisms are used to assess overall achievements. Whereas the informal assessment of data is obtained through activities carried out by individuals who are anecdotal and evidence obtained from observations during the learning process takes place, in a way that is less determined than formal assessments. Informal assessment can include a series of strategies, including class work and ongoing work, questions, class discussion, group work, observation and monitoring, student evaluation and self-reflection, and feedback.

Technology and vocational education, both implemented through formal and non-formal education, is an integral part of the national education system. Vocational education has a direct relationship with the process of industrialization, especially when it is linked to its function, namely preparing industrial workers who have expertise or competence in their fields so that they can compete at the global level. Vocational education in Indonesia is secondary education, aiming to prepare students, especially to be able to work in specific fields, continue to higher education or entrepreneurship. Vocational Education graduates are recognized as having expertise of the operator and technician level (levels 2 and 3 of the Indonesian National Qualification Framework / KKNI) in specific fields, such as business, manufacturing, electronics, electricity, machinery, automotive, telecommunications, agriculture, household, and others. Thus, vocational education graduates, in general, are required to have at least level 2 and three skills in the field of science and skills to work in certain positions or occupations.

The success of an educational institution in achieving its desired goals is determined by effective learning strategies, complete media, sophisticated practice equipment, excellent curriculum, and a reliable evaluation system. The evaluation system for vocational education, especially at the level of Vocational High School (SMK), the measurement of learning outcome is done through formative, sub-summative, summative, school exams, and National Examinations. Students are required to take a competency test of knowledge at the end of the semester if they want to obtain a certificate of expertise. The skills competency test has two parts, namely the vocational theory test and the professional practice test. Professional theory tests are conducted in the form of written tests both objective tests and subjective tests, whereas the professional practice test is carried out with a skills test and performance test.

In the Minister of Education and Culture Regulation of the Republic of Indonesia, Number of 66, 2013, explained that education assessment was a process of gathering and managing information. It is used to measure the achievement of students' learning outcomes. Including authentic assessment, self-assessment, portfolio-based assessment, daily tests, midterm tests, tests end of semester, competency level test, national exam and school exam. In carrying out the education, assessment is carried out formally and informally. Midterm tests, end of semester tests, competency level exams, national exams, and school exams are usually done officially. Not only self-assessment (religious and social attitudes), portfolio-based assessments, but also the daily tests tend to be conducted in informal situations. Informal assessments cannot wholly 
replace formal evaluations. Both are needed to assess learning outcomes.

Some studies evaluating learning outcomes in vocational schools raise issues in concerning the implementation of formal assessment, while few studies have examined informal assessment. Based on the above background, this study explores five key areas: (1) The extent to which informal assessment is applied by vocational high school teachers in learning outcome's assessment; (2) If there are any significant correlations between informal assessments for each of the four core competencies: religious, social, knowledge, and skills; (3) The main reasons vocational high school teachers conduct informal assessments; (4) The extent to which vocational high school teachers conduct informal assessment of the four core competencies; and (5) The data collection techniques used by vocational high school teachers when applying informal assessments.

The objectives of this study include: (1) Surveying the tendency of carrying out informal assessments of the core competencies of students at the Vocational High School conducted by teachers, (2) Identifying the techniques used by teachers in carrying out informal assessments and (3) identify the problem of informal evaluation by the teacher.

\section{Methodology}

The research used a survey method and stratified random sampling, with the results of the study displayed in a qualitative discrete format. Questionnaires were used as the research instruments. The distribution of the study respondents is provided in Table 1, comprising of 183 vocational high school teachers, from 98 schools, in 21 Indonesian provinces.

The instrument validity was calculated by the Pearson product moment correlation formula, and the instrument reliability was calculated by the Alpha formula. The results of the calculation of validity ( $r$ ) are compared with the $r$ value in the decision table. Conversely, if r count $<\mathrm{r}$ table, the item is declared invalid. The $r$ table is used to identify the critical product moment at a real level of 5\%. Invalid items are immediately rejected. Table 2 outlines the results.

The coherence of the measurement results, or the value of reliability, is determined based on the reliability coefficient of decisively which is acceptable to decide the instrument that the value of Alpha is $\geq 0.5$. As the Alpha value $=0.646 \geq 0.5$, it can be concluded that the instrument is reliable.

Table 1. Distribution of Respondents

\begin{tabular}{|c|c|c|c|c|c|c|c|}
\hline \multirow{3}{*}{ No. } & \multirow{3}{*}{ Province } & \multicolumn{6}{|c|}{ Sample } \\
\hline & & \multicolumn{3}{|c|}{$\begin{array}{c}\text { Respondents (Teacher) } \\
\mathrm{n}=183\end{array}$} & \multicolumn{3}{|c|}{$\begin{array}{c}\text { School unit } \\
\mathrm{n}=142\end{array}$} \\
\hline & & Public & Private & Total & Public & Private & Total \\
\hline 1. & DKI Jakarta & 32 & 24 & 56 & 1 & 10 & 11 \\
\hline 2. & West Java & 13 & 7 & 20 & 10 & 6 & 16 \\
\hline 3. & Banten & 2 & 15 & 17 & 2 & 13 & 15 \\
\hline 4. & Central Java & 5 & 9 & 14 & 5 & 2 & 7 \\
\hline 5. & East Java & 7 & 2 & 9 & 5 & 1 & 6 \\
\hline 6. & South Sumatra & 4 & 1 & 5 & 4 & 1 & 5 \\
\hline 7. & West Kalimantan & 26 & 3 & 29 & 5 & 3 & 8 \\
\hline 8. & Lampung & 2 & 2 & 4 & 2 & 2 & 3 \\
\hline 9. & Yogyakarta & 2 & 2 & 4 & 2 & 1 & 3 \\
\hline 10. & Bangka Belitung & 1 & 1 & 2 & 1 & 1 & 2 \\
\hline 11. & North Sumatra & 2 & 0 & 2 & 2 & 0 & 2 \\
\hline 12. & Bengkulu & 1 & 0 & 1 & 1 & 0 & 1 \\
\hline 13. & West Sumatra & 2 & 0 & 3 & 2 & 0 & 2 \\
\hline 14. & East Kalimantan & 1 & 0 & 1 & 1 & 0 & 1 \\
\hline 15. & South Kalimantan & 2 & 0 & 2 & 2 & 0 & 2 \\
\hline 16. & Southeast Sulawesi & 1 & 0 & 1 & 1 & 0 & 1 \\
\hline 17. & North Sulawesi & 1 & 3 & 1 & 1 & 1 & 2 \\
\hline 18. & South Sulawesi & 1 & 1 & 1 & 1 & 1 & 2 \\
\hline 19. & Central Sulawesi & 2 & 0 & 2 & 2 & 0 & 2 \\
\hline 20. & Maluku & 1 & 0 & 1 & 1 & 0 & 1 \\
\hline 21. & East Nusa Tenggara & 2 & 2 & 2 & 2 & 2 & 4 \\
\hline & Total & 111 & 72 & 183 & 54 & 44 & 98 \\
\hline
\end{tabular}


Table 2. Results of the product moment correlation test to calculate the validity of the research instruments.

\begin{tabular}{|c|c|c|c|}
\hline Number of Questions & $r$ count $>r$ table & $\mathrm{t}$ count $<$ tsiq. & Conclusion \\
\hline $\mathrm{X} 1$ & - & - & Invalid \\
\hline $\mathrm{X} 2$ & $.341>.138$ & $.000<.05$ & Valid \\
\hline $\mathrm{X} 3$ & $.450>.138$ & $.000<.05$ & Valid \\
\hline $\mathrm{X} 4$ & $.676>.138$ & $.000<.05$ & Valid \\
\hline $\mathrm{X} 5$ & $.631>.138$ & $.000<.05$ & Valid \\
\hline X6 & $.190>.138$ & $.000<.05$ & Valid \\
\hline $\mathrm{X} 7$ & $.628>.138$ & $.000<.05$ & Valid \\
\hline $\mathrm{X} 8$ & $.570>.138$ & $.000<.05$ & Valid \\
\hline X9 & $.559>.138$ & $.000<.05$ & Valid \\
\hline $\mathrm{X} 10$ & $.253>.138$ & $.001<.05$ & Valid \\
\hline X11 & $.285>.138$ & $.285>.05$ & Valid \\
\hline $\mathrm{X} 12$ & $.273>.138$ & $.000<.05$ & Valid \\
\hline $\mathrm{X} 13$ & $.237>.138$ & $.001<.05$ & Valid \\
\hline X14 & $.175>.138$ & $.018<.05$ & Valid \\
\hline $\mathrm{X} 15$ & $.210>.138$ & $.004<.05$ & Valid \\
\hline $\mathrm{X} 16$ & $.026<.138$ & $.722>.05$ & Invalid \\
\hline $\mathrm{X} 17$ & $.038<.138$ & $.608>.05$ & Invalid \\
\hline $\mathrm{X} 18$ & $224<.138$ & $.002>.05$ & Valid \\
\hline
\end{tabular}

\section{Findings}

\section{The Extent to which Informal Assessment is Applied by Vocational High School Teachers in Learning Outcomes Assessment}

The results show an average score of 8.6 for the 183 respondents, with a maximum score of 15 , a mode of 7, a median of 8 , and a standard deviation of 2.53 . The survey results show that $76 \%$ of the respondents undertake informal assessments for religious competency, $63 \%$ for social competency, $34 \%$ for knowledge competency and $35 \%$ for skills competency. If the average value is included in the criteria, the extent to which informal assessment is used by vocational teachers is within the active category. The teachers have tendency to use the informal assessment for the four core competencies. The results are shown in Figure 1.

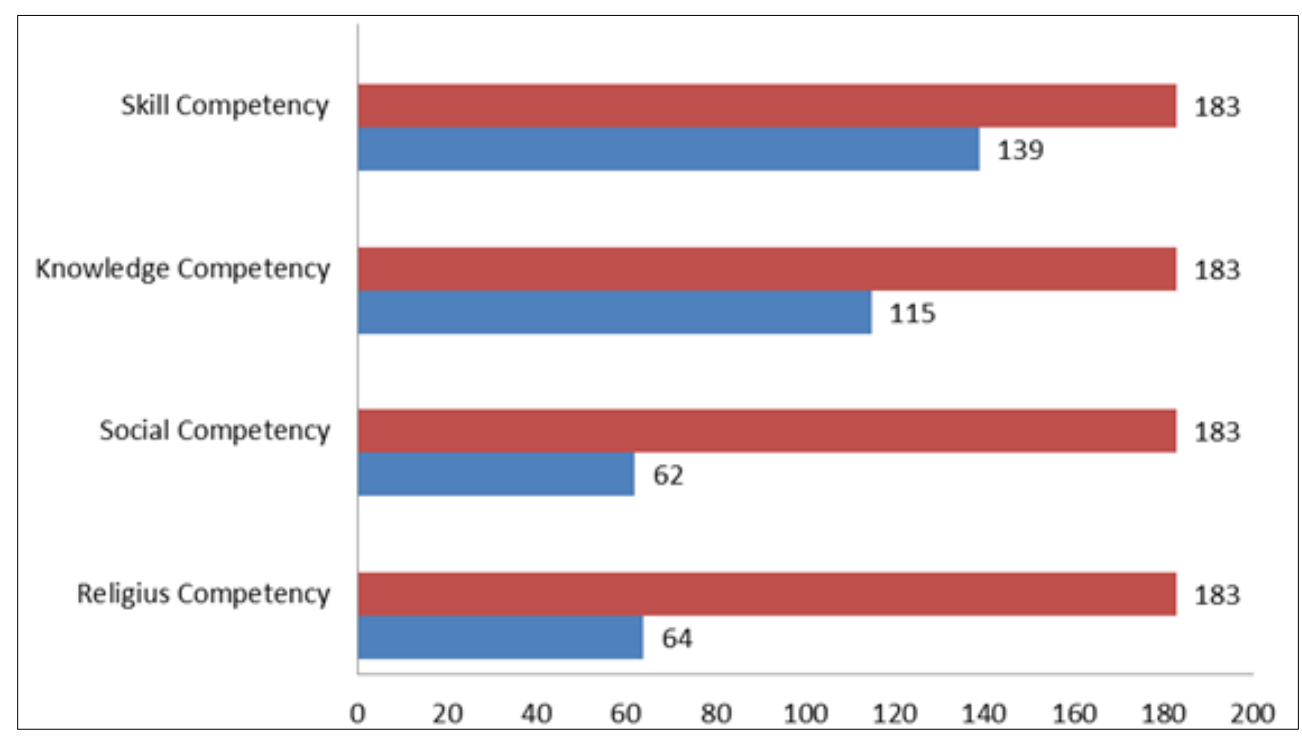

Figure 1. The extent to which teachers conduct informal assessments for the four core competencies 
While skills competency reaches out the highest respondent which was 139 , the social competency was the least one that only 62 teachers implemented the informal assessment. On the other side, there were 115 and 64 teachers who used the informal assessment in knowledge competency and social competency respectively.

\section{Description of the Correlation between Informal Assessments of Each Core Competency}

The data shows the tendency for teachers to use informal assessments when measuring moral competence, followed by social competence. This shows that only a low proportion of teachers use informal assessments to assess knowledge and skills competencies. The correlation results of informal assessment between the core competencies are provided in Table 3.

The results in Table 3 demonstrate that there is a significant correlation in informal assessment between religious competence and social competence ( $\mathrm{r}$ count $=.244 \geq .138$; Sig. [2-tailed] $0.001<.050$, and between knowledge competence and skills competence $(.721 \geq .138)$ Sig.[(2-tailed] .000 < .05). However, there is no significant correlation between informal assessments of religious and social competencies and knowledge and skills competencies. The correlation index between religious competence and knowledge competence is $-.033 \leq .138 \mathrm{Sig}$. (2-tailed) $.653>.05$. The correlation index between religious competence and skill competence is $-.014 \leq .138$ ) Sig. (2-tailed) $.855>.05$. The correlation index between social competence and knowledge competence is -.023 $\leq .138$ ) Sig. (2-tailed) $.758>.05$. The correlation index between social competence and skill competence is $(.010$ $\leq .138$ ) Sig. (2-tailed) .896 > .05.

\section{Description of Vocational High School Teachers' Reasons for Conducting Informal Assessments}

Table 4 shows that teachers of non-vocational subjects applied informal assessments for religious competencies. The informal assessment also applies to knowledge competencies and social competencies. Table 4 shows that very few vocational subject matter teachers evaluate informal skills competency, for example, no religious teachers apply informal assessment of religious skills competencies. In contrast, more than half of the physical education teachers or sports teachers use informal assessment.

The research indicates that vocational high school teachers conduct informal assessments because it is recommended by the school administration. All teachers (100\%) claim that schools encourage teachers to conduct informal assessments. This school recommendation is used as the main reason for teachers to implement the informal evaluation.

Table 3. Correlation of informal assessment between core competencies

\begin{tabular}{|c|c|c|c|c|}
\hline \multirow{2}{*}{ Competencies } & \multicolumn{4}{|c|}{ Pearson Correlations } \\
\hline & K11 & K12 & K13 & K14 \\
\hline Religius Competency (KI1) & 1 & $.244 * *$ & .033 & -.014 \\
\hline Sig. (2-tailed) & & .001 & .653 & .855 \\
\hline Social Competency (K12) & & 1 & -.023 & 010 \\
\hline Sig. (2-tailed) & & & .758 & .896 \\
\hline Knowledge Competency (KI3) & & & & $.721 * *$ \\
\hline Sig. (2-tailed) & & & 1 & .000 \\
\hline Skills Competency (KI4) & & & & 1 \\
\hline
\end{tabular}

**. Correlation is significant at the 0.01 level (2-tailed).

Table 4. Comparison of Vocational Subject Teachers and Non-Vocational Subject Teachers in the Application of Informal Assessment of the Core Competencies.

\begin{tabular}{|c|c|c|c|c|}
\hline \multirow{2}{*}{\begin{tabular}{c} 
Group Subjects \\
\cline { 2 - 5 }
\end{tabular}} & $\begin{array}{c}\text { Religious } \\
\text { competency }\end{array}$ & Social Competency & $\begin{array}{c}\text { Knowledge } \\
\text { Competency }\end{array}$ & Skills competency \\
\hline $\begin{array}{c}\text { Mathematics, Biology, and Physics } \\
(\mathrm{n}-20)\end{array}$ & 100 & 100 & 90 & 25 \\
\hline Social Sciences (n=7) & 86 & 70 & 30 & 43 \\
\hline Physical education (n=5) & 100 & 60 & 40 & 60 \\
\hline Religion (n=3) & 100 & 100 & 30 & 0 \\
\hline Language (n= 10) & 100 & 70 & 60 & 10 \\
\hline
\end{tabular}




\section{Description of the Extent to Which Vocational High School Teachers Conduct Informal Assessments for the Four Core Competencies}

Figure 2 shows that $80 \%$ of teachers of automotive and electrical subjects applied informal assessments to measure religious competence. Likewise, $80 \%$ of teachers in the field of Electronics used informal assessments for social competence, while $60 \%$ of information technology teachers used informal assessments to evaluate skills competency.

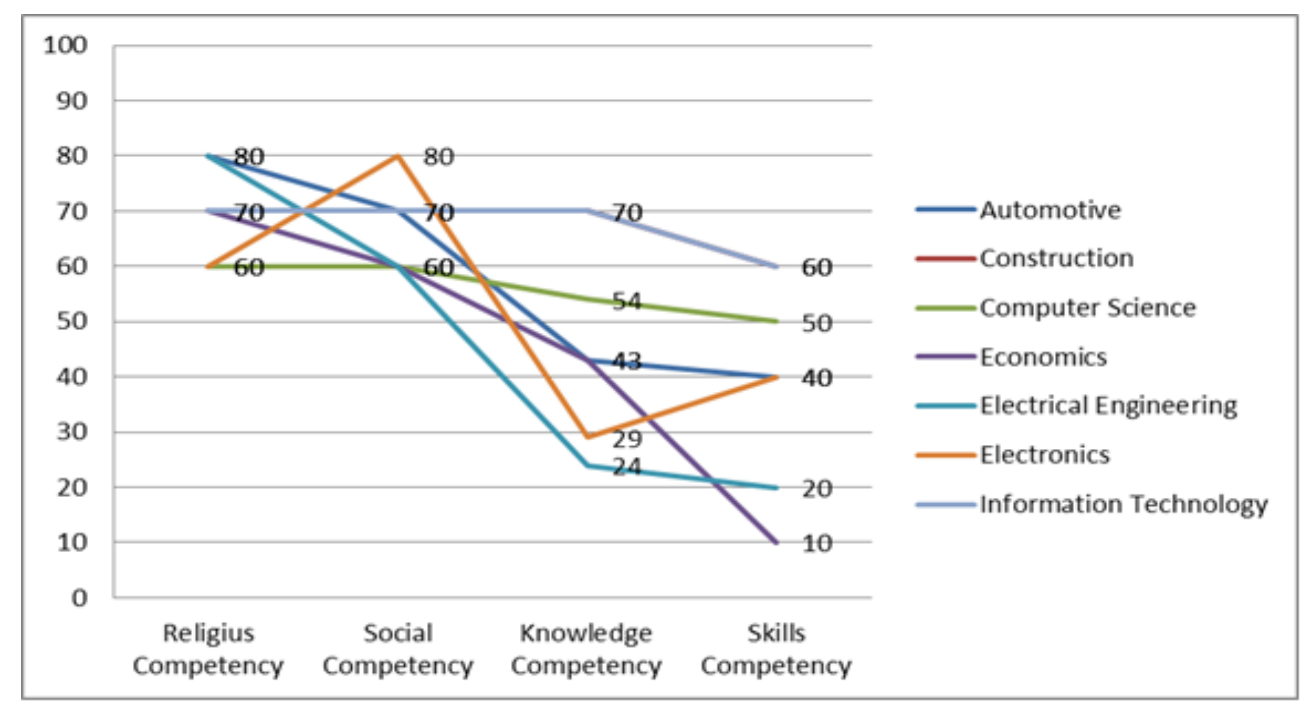

Figure 2. The application of informal assessment to the four core competencies in vocational high school subjects

\section{Informal Assessment Data Collection Techniques}

Table 5 demonstrates that the majority of teachers prefer an is an observation checklist method of informal assessment (80\%) followed by assignments (44\%), discussions with peers (38\%), and the results of homework (22\%).

Table 5. Data collection techniques in informal assessments by vocational teachers.

\begin{tabular}{|c|c|c|}
\hline Data Collection Techniques & $\begin{array}{c}\text { Respondent } \\
\text { (n = 183) }\end{array}$ & Percentage (\%) \\
\hline Observation Checklist & 146 & 80 \\
\hline Homework & 41 & 38 \\
\hline Peer Discussion & 70 & 44 \\
\hline Assignment & 80 & 22 \\
\hline
\end{tabular}

Table 6 indicates that there is no correlation between the assignment assessment technique and social competence, and that there is a negative correlation with religious competency. Similarly, the observation checklist technique is not correlated with knowledge competence and skill competence.

Table 6. Techniques for implementing Informal assessments with measured core competencies.

\begin{tabular}{|c|c|c|c|c|}
\hline \multirow{2}{*}{ Competency } & \multicolumn{3}{|c|}{ Measurement Techniques } \\
\cline { 2 - 5 } & $\begin{array}{c}\text { Observation } \\
\text { Checklist }\end{array}$ & Homework & Assignment & Teacher-colleague discussion \\
\hline Religious Competency & $.292^{* *}$ & $.155^{*}$ & -.071 & $.247^{* *}$ \\
Sig. (2-tailed) & .000 & .037 & .0339 & .001 \\
\hline Social Competency & $.331^{* *}$ & $.169^{*}$ & -.045 & $.404^{* *}$ \\
Sig. (2-tailed) & .000 & .000 & .022 & .000 \\
\hline Knowledge Competency & -.110 & $.501^{* *}$ & $.610^{* *}$ & .000 \\
Sig. (2-tailed) & .137 & .000 & .000 & $.219^{* *}$ \\
\hline Skills Competency & -.104 & $.438^{* *}$ & $.599^{* *}$ & .003 \\
Sig. (2-tailed) & .160 & .000 & .000 & \\
\hline
\end{tabular}

** Correlation is significant at the 0.01 level (2-tailed) 


\section{Discussion}

The results of the study show that vocational high school teachers apply informal assessments in almost all subjects. Informal evaluation is undertaken by the teacher on the advice of the school administration. However, the distribution of the number of teachers for each competency is different. The study revealed that $76 \%$ of the respondents conduct informal assessments for religious competency, $63 \%$ for social competency, $34 \%$ for knowledge competency, and $35 \%$ for skills competency. Assessment for learning is any assessment aimed to serve the purpose offer which the purposes of accountability, or of ranking, or of certifying competence. Such assessment becomes a 'formative assessment' when the evidence is actually used to adapt the teaching work to meet learning needs [21].

Teachers tend to apply informal assessments using observation techniques, assessing homework, assessing assignments, and having discussions with their peers. According to [22], by peer evaluation, students can learn how to solve their own problems and improve their own work before approaching the teacher. Some teachers use only one method or approach depending on the characteristics of the subject. [23] studied the informal assessment practices of four teachers during science investigation classes and measured student learning outcomes with various embedded assessments. The results show that the informal formative assessment practices of the four teachers differ significantly. These findings reinforce the argument that the methods of informal assessment and informal data collection do not refer to any accepted standards.

Teachers demonstrate an inclination to obtain informal assessment data using observation checklists, oral tests, and questionnaires. Observation checklists are used by most teachers because observation is the most practical assessment technique, can be undertaken at any time, and is cost-effective [24]. In [24] study, the observation sheet was used by most vocational teachers to measure religious competency (59\%), and social competency (58\%). This is in line with the results of [25] research showing that $48 \%$ of secondary school teachers conduct competency assessments through observation sheets and $47 \%$ use oral tests. Setiadi's study found that $91 \%$ of teachers use written examinations to measure knowledge competence formally, followed by oral tests (80\%) and assignments (60\%).

The fundamental issue in informal assessment with the observation technique is the validity of the observations. According to [26], teacher observations are valid insofar as they are supported by appropriate evidence and interpreted correctly; i.e., whether the recorded evidence accurately represents the observed student performance and the interpretation of this evidence is justified. Accurate recording requires a transparent and unbiased perception of student performance, and a justified interpretation requires careful consideration of every factor that might have contributed to the performance.

\section{Conclusions}

This study demonstrates that most vocational high school teachers apply informal assessments, and these assessments are applied across most subjects. The study also found a significant relationship between informal assessments of religious and social competencies and between knowledge and skills competencies. No significant correlation was found between the informal assessment of religious and social competencies (attitude-based) and knowledge and skills competencies (knowledge-based). The study identified that teachers are encouraged by the school administration to undertake informal assessments; however, they also undertake informal assessment under their own initiative in order to complement the scores of students whose formal assessment results are lacking and to assess students who have problems with their learning outcomes. Finally, the study found that informal assessment techniques are carried out by teachers through daily observation checklists, discussions with peers, assignments, and homework, with some teachers applying a single tool or a combination of these tools depending on the characteristics of the subject. This study suggests that the ability of vocational high school teachers' should be improved so they can carry out informal assessments and make the results of the student learning outcomes more authentic. The study recommend the teachers in vocational high school implement the informal assessment in order to evaluate the students' outcome objectively.

\section{REFERENCES}

[1] Reynolds, C.R., Livingston, R.B., \& Wilson, V. (2009). Measurement and Assessment in Education. Pearson. New Jersey Columbus, Ohio.

[2] Dunn, L., Morgan, C., O’Reilly, M., \& Parry, S. (2004). The Student Assessment Handbook. New York: Routledge Falmer.

[3] Biggs, J. (2000). Teaching for Quality Learning at University. USA: SRHE and Open University Press.

[4] Brew, A. (2003). Towards Autonomous Assessment: Using Self-Assessment and Peer Assessment. In S. Brown, \& A. Glasner (Eds.), Assessment Matters in Higher Education: Choosing and Using Diverse Approaches, Buckingham, UK: SRHE and Open University Press.

[5] Krasne, S., Wimmers, P.F., Relan, A., \& Drake, T.A. (2006). Differential effects of two types of formative assessment in 
predicting performance of first-year medical students. Adv Health Sci Educ Theory Pract, 11, 155-171.

[6] Bell, B., Bell, N., \& Cowie, B. (2001). Formative assessment and science education. Dordrecht, Netherlands: Kluwer.

[7] Cazden, C.B. (2001). Classroom discourse: The language of teaching and learning (2nd ed.). Portsmouth, NH, USA: Heinemann.

[8] Duschl, R. A. (2003). Assessment of inquiry. In J. M. Atkin \& J. E. Coffey (Eds.), Everyday assessment in the science classroom (pp. 41-59). Arlington, VA, USA: National Science Teachers Association Press.

[9] William, D., Lee, C., Harrison, C., \& Black, P. (2004). Teachers developing assessment for learning: impact on student achievement. Assessment in Education, 11(1), 49-65.

[10] Fred, R.V. (2013). Informal Assessment. Encyclopedia of Autism Spectrum Disorders, New York: Springer Link.

[11] Jordan, B., \& Putz, P. (2004). Assessment as practice: Notes on measures, tests, and targets. Human Organization, 63, 346-358.

[12] Lampert, M. (2001). Teaching problems and problems of teaching. New Haven: Yale University Press.

[13] Assessment Reform Group. (2002). Assessment for learning: 10 principles. Research based principles to guide classroom practice. Retrieved July 1, 2010, from: http://www.assessment-reform-group.org.uk/CIE3.pdf.

[14] Black, P. (2009). From frequent testing to interactive dialogue: Diversity and challenge. Guest's editor introduction. Journal of Multidisciplinary Evaluation, 6(12), iii-vi.

[15] Leahy, S., Lyon, C., Thompson, M., \& Wiliam, D. (2005). Classroom assessment: Minute by minute, day by day. Educational leadership, 63(3), 18-24.

[16] Leung, C., \& Mohan, B. (2004). Teacher formative assessment and talk in classroom contexts: Assessment as discourse and assessment of discourse. Language Testing, 21(3), 335-359.

[17] Moss, P. A. (2008). Sociocultural implications for the practice of assessment I: Classroom assessment. In P. A.
Moss, D. Pullin, J. P. Gee, E. H. Haertel, \& L. J. Young (Eds.), Assessment, equity, and opportunity to learn. New York: Cambridge University Press

[18] Heritage, M. (2010). Formative assessment. Making it happen in the classroom. Corwin, USA: Thousand Oaks, CA.

[19] De Leon, V., \& Allan, A. (2015). Research Brief: The Informal Formative Assessment Cycle as a Model for Teacher Practice, Teaching Tools for Science, Technology, Engineering and Math (STEM) Education. Retrieved from https://STEMteachingtools.org/brief/16

[20] Navarrete, C., Wilde, J., Nelson, C., Martinez, R., \& Hargett, G. (1990). Informal Assessment in Educational Evaluation: Implications for Bilingual Education Programs. Washington, DC: National Clearinghouse for Bilingual Education.

[21] Black, P., Harrison, C., Lee, C., Marshall, B., \& Wiliam, D. (2004). Working inside the Black Box: Assessment for Learning in the Classroom. Phi Delta Kappan, 86(1), 8-21. https://doi.org/10.1177/003172170408600105

[22] Gibbs, G. (2003). Using Assessment Strategically to Change the Way Students Learn. In S. Brown, \& A. Glasner, (Eds.), Assessment Matters in Higher Education: Choosing and Using Diverse Approaches, Buckingham, UK: SRHE and Open University Press.

[23] Ruiz-Primo, M.A., \& Erin M. Furtak, E.M. (2007) Exploring Teachers' Informal Formative Assessment Practices and Students' Understanding in the Context of Scientific Inquiry. Journal of Research in Science Teaching, 44(1), 57-84.

[24] Retnawati, H., Hadi, S., \& Nugraha, A. C. (2016). Vocational High School Teachers' Difficulties in Implementing the Assessment in Curriculum 2013 in Yogyakarta Province of Indonesia. International Journal of Instruction, 9(1), 33-48.

[25] Setiadi, H. (2016). Pelaksanaan Penilaian Pada Kurikulum 2013. Jurnal Penelitian dan Evaluasi Pendidikan, 20(2): 166-178.

[26] Maxwell, G.S. (2001). Teacher Observation in Student Assessment, Discussion Paper. School of Education. Queensland: The University of Queensland School Curriculum Council. 